\title{
Synthesis of glycoconjugate fragments of mycobacterial phosphatidylinositol mannosides and lipomannan
}

\author{
Benjamin Cao, Jonathan M. White and Spencer J. Williams*
}

\section{Full Research Paper}

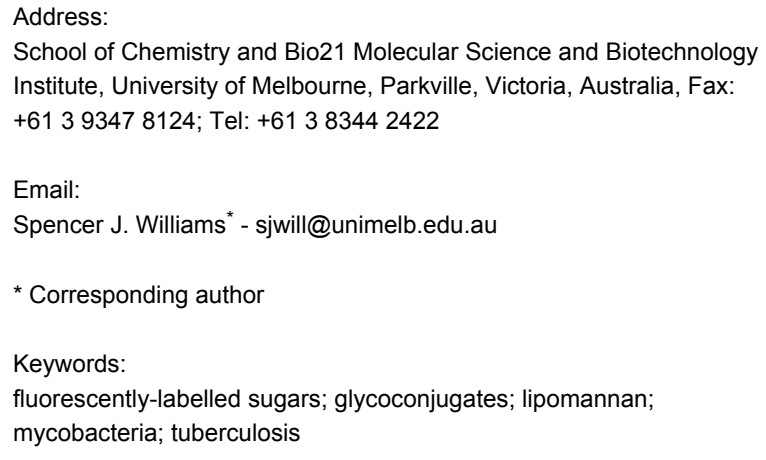

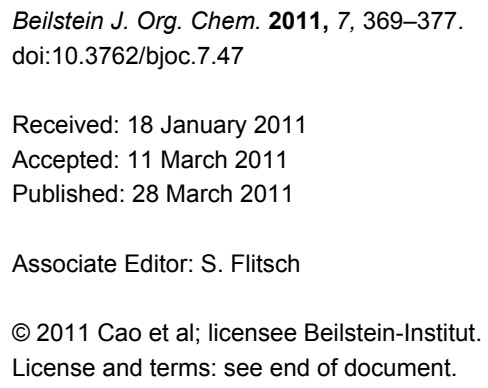

\begin{abstract}
Mycobacterium tuberculosis, the causitive agent of tuberculosis (TB), possesses a complex cell wall containing mannose-rich glycophospholids termed phosphatidylinositol mannosides (PIMs), lipomannan (LM), and lipoarabinomannan (LAM). These glycophospholipids play important roles in cell wall function and host-pathogen interactions. Synthetic PIM/LM/LAM substructures are useful biochemical tools to delineate and dissect the fine details of mannose glycophospholipid biosynthesis and their interactions with host cells. We report the efficient synthesis of a series of azidooctyl di- and trimannosides possessing the following glycan structures: $\alpha$-Man-1,6- $\alpha$-Man, $\alpha$-Man-1,6- $\alpha$-Man-1,6- $\alpha$-Man, $\alpha$-Man-1,2- $\alpha$-Man-1,6- $\alpha$-Man and 2,6-di-( $\alpha$-Man)- $\alpha$ Man. The synthesis includes the use of non-benzyl protecting groups compatible with the azido group and preparation of the branched trisaccharide structure 2,6-di-( $\alpha$-Man)- $\alpha$-Man through a double glycosylation of a 3,4-butanediacetal-protected mannoside. The azidooctyl groups of these synthetic mannans were elaborated to fluorescent glycoconjugates and squaric ester derivatives useful for further conjugation studies.
\end{abstract}

\section{Introduction}

The incidence of TB is now at an all-time historical high with over 2 billion people infected globally [1]. TB is the leading infectious killer of people with HIV/AIDS and is second only to HIV/AIDS as an infectious cause of death for adults [2]. It is sobering that it has been more than 40 years since the last frontline TB drug (rifampicin) was deployed [3]. Drug resistance is now widespread and growing, underscoring the need for the development of new therapies to bolster the physician's armamentarium for TB control [3]. Many existing TB drugs target aspects of mycobacterial cell wall biosynthesis (e.g., thiacetazone, isoniazid, ethambutol, pyrazinamide, and ethionamide) with the cell wall of the tubercule bacillus being widely agreed as a promising target for new drugs [4,5]. The cell wall of all mycobacteria is especially rich in lipids and polysaccharides, 
with the major component being a macromolecule composed of mycolic acids, arabinogalactan, and peptidoglycan, termed the mycolyl-arabinogalactan-peptidoglycan complex [6,7]. One intriguing class of cell wall associated molecules are those based on a phosphatidylinositol (PI) core, which include the PIMs, LM, and LAM [8].

Through studies with gene deletion mutants of mycobacterial strains, several steps in the biosynthesis of the PIMs, LM and LAM have been shown to be essential for bacterial survival and it is now well appreciated that they are crucial cell-surface molecules that mediate host-pathogen interactions $[8,9]$. Biochemical studies support the general biosynthetic relationship PIMs $\rightarrow$ LM $\rightarrow$ LAM, although it is also clear that $\mathrm{Ac}_{2} \mathrm{PIM}_{2}$ and $\mathrm{Ac}_{2} \mathrm{PIM}_{6}$ represent important metabolic end products in their own right [10]. Scheme 1 summarizes the biosynthesis of the mannan core of the PIMs, LM and LAM. PIM biosynthesis commences with the stepwise transfer of two mannosyl residues onto inositol, catalyzed by the GDPmannose dependent $\alpha$-mannosyltransferases PimA [11] and PimB' $[12,13]$, followed by acylation by the acyltransferase (Rv2611c) to give AcPIM $_{2}[14,15]$. Additional $\alpha$-1,6-mannosylations of $\mathrm{AcPIM}_{2}$ give rise to $\mathrm{AcPIM}_{3}$ and $\mathrm{AcPIM}_{4}$, the last of which is hypothesized to be a key biosynthetic precursor for the synthesis of the so-called polar PIMs, AcPIM 5 and $\mathrm{Ac}_{2} \mathrm{PIM}_{6}$, and LM and LAM [16].

The biosynthesis of LM and LAM (Scheme 1) commences from $\mathrm{AcPIM}_{4}$ with the installation of a linear $\alpha$-1,6-linked mannan backbone on the terminal mannose [17]. Two $\alpha-1,6$-mannosyltransferases, MptB and MptA, have been identified to be involved in the elongation of the LM backbone $[18,19]$. The linear backbone is then elaborated with single $\alpha$-1,2-linked mannose residues to give mature LM [20]. LAM is formed by addition of arabinan to the penultimate mannose residue of LM, and is subsequently capped with a variety of groups including inositol phosphate, 5-methylthioxylose and its sulfoxide, and short 1,2-mannose oligomers [7].

Studies into the biosynthesis of the PIMs, LM and LAM have been greatly facilitated by the development of glycomimetic compounds. Homogeneous synthetic substructures have been used to deconvolute aspects of substrate recognition by biosynthetic enzymes and the structural determinants of host-pathogen interactions including antibody recognition and immune pattern-recognition systems such as the dendritic cell specific intercellular adhesion molecule-grabbing non-integrin (DCSIGN) [8]. Thus, while total syntheses of many PIM structures have now been reported, the synthesis of substructures remains a worthwhile endeavor as these are useful to clarify fine details of enzymatic substrate recognition and are substantially easier to prepare $[4,8]$. As a shining example, synthetic octyl $\alpha-1,6-$ linked oligomannoside analogues of the 1,6-mannan core are effective substrates for mycobacterial cell free systems [21-23], and were used to confirm the activity of the polymerizing $\alpha-1,6-$ mannosyltransferases MptB and MptA [18,19], and to demonstrate functional compartmentalization of PPM synthase activity and MptB/MptA [24]. They have also been used as glycolipid substrates supporting the development of inhibitors of PIM/LM/ LAM biosynthesis [25-28]. Various 1,2-linked aminooctyl oligomannosides corresponding to the capping groups of ManLAM were prepared and conjugated to carrier proteins and used to study antibody reactivity in a serological TB assay $[29,30]$. A complete set of the phosphoglycan head groups of

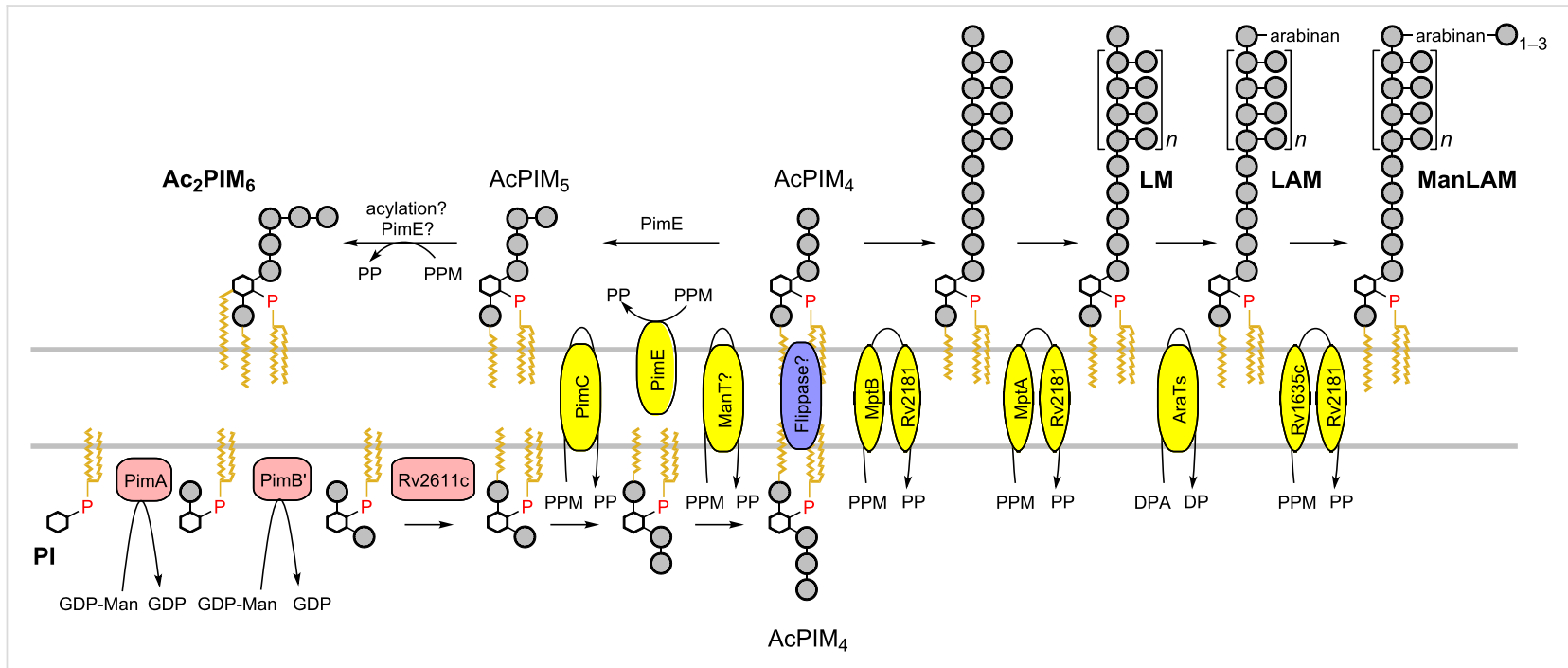

Scheme 1: Indicative topology model for the biosynthesis of the glycophospholipids PIMs, LM and LAM in mycobacteria. The timing for translocation of PIM intermediates across the membrane is unclear. Hexagon = myo-inositol; closed circle $=$ mannose; $\mathrm{P}=$ phosphate. 
$\mathrm{PIM}_{1}-\mathrm{PIM}_{6}$ with a thiol linker in place of the diacylglycerol were prepared and, following immobilization on glass slides, their binding to the lectin DC-SIGN was assessed [31].

Significant questions remain in the area of PIM/LM/LAM biosynthesis that could be assisted by suitable well-defined mannan substructures. For example, the identity of the $\alpha-1,2-$ mannosyltransferase(s) involved in the conversion of $\mathrm{AcPIM}_{4}$ $\rightarrow \mathrm{AcPIM}_{5} \rightarrow \mathrm{Ac}_{2} \mathrm{PIM}_{6}$ remain incompletely characterized [17]. Similarly, the timing of the introduction of the single $\alpha$-1,2-mannose residues onto the $\alpha$-1,6-linked mannan core versus the elongation of this core is unclear [32]. For these reasons, we have undertaken the synthesis of a suite of fragments of the PIMs and LM, 1-4, and report their elaboration into glycoconjugates $\mathbf{5 - 1 0}$ for use as biological reagents to study PIM/LM/LAM biosynthesis and immunogenicity (Figure 1 and Figure 2). The azidooctyl aglycon has particular utility in this regard because of its (i) lipophilicity allowing biphasic partitioning between butanol/water or purification by reversed-phase extraction, (ii) ability to be reduced to an aminooctyl chain for use in squarate conjugation chemistry, and (iii) capacity to be conjugated with fluorescent terminal alkynes using the $\mathrm{Cu}(\mathrm{I})$-catalyzed azide-alkyne cycloaddition (CuAAC) reaction $[33,34]$.

\section{Results and Discussion}

Since their introduction by Palcic and co-workers [35], hydrophobic alkyl glycosides have proven to be valuable derivatives for enzymatic assays, as their lipophilic nature allows easy product isolation by either reversed-phase chromatography or simple solvent partitioning. Incorporation of an azidooctyl group confers many of the same benefits as an octyl aglycon, with the additional advantage that the azido group may be elaborated into glycoconjugates. However, the synthesis of azidooctyl glycosides can be challenging as the use of reductively-removed protecting groups such as benzyl ethers must be avoided owing to their incompatibility with the azido group when using $\mathrm{H}_{2} / \mathrm{Pd}$ or $\mathrm{Na} / \mathrm{NH}_{3}$. We therefore sought to develop a synthesis based on the use of esters, silyl ethers and acetals only.

\section{Synthesis of monosaccharide building blocks}

Glycosidation of 8-azidooctan-1-ol (Supporting Information File 2) using glycosyl bromide 11 [36] in the presence of AgOTf, and debenzoylation of the crude product gave 12 in $81 \%$ yield over 2 steps (Scheme 2). Regioselective silylation of the primary alcohol of $\mathbf{1 2}$ with TPSCl followed by benzoylation of the remaining hydroxyl groups afforded the glycoside 13, which was desilylated with HF.pyridine complex to yield 14. This chemoselective transformation uses conditions that are similar to those reported by Tam et al. [23], and result in desilylation in a significantly shorter period than that previously reported using $\mathrm{HCl}$ in $\mathrm{MeOH} / \mathrm{Et}_{2} \mathrm{O}$ [22]. The diol 15 was prepared by treatment of $\mathbf{1 2}$ with 2,3-butanedione and trimethyl orthoformate in the presence of catalytic acid in refluxing $\mathrm{MeOH}$ (Scheme 2) [37]. Trace amounts of the corresponding methyl glycoside were also obtained, arising from limited methanolysis of the glycosidic linkage.
A

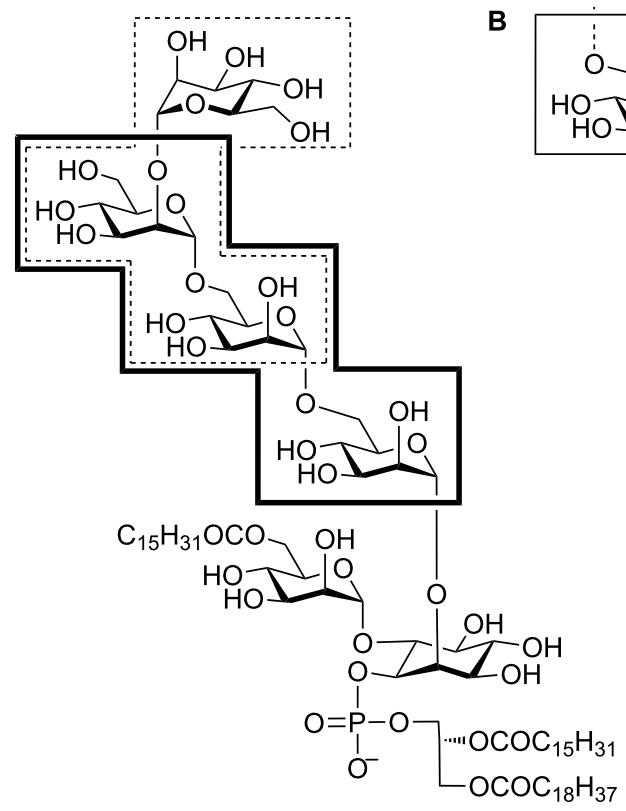

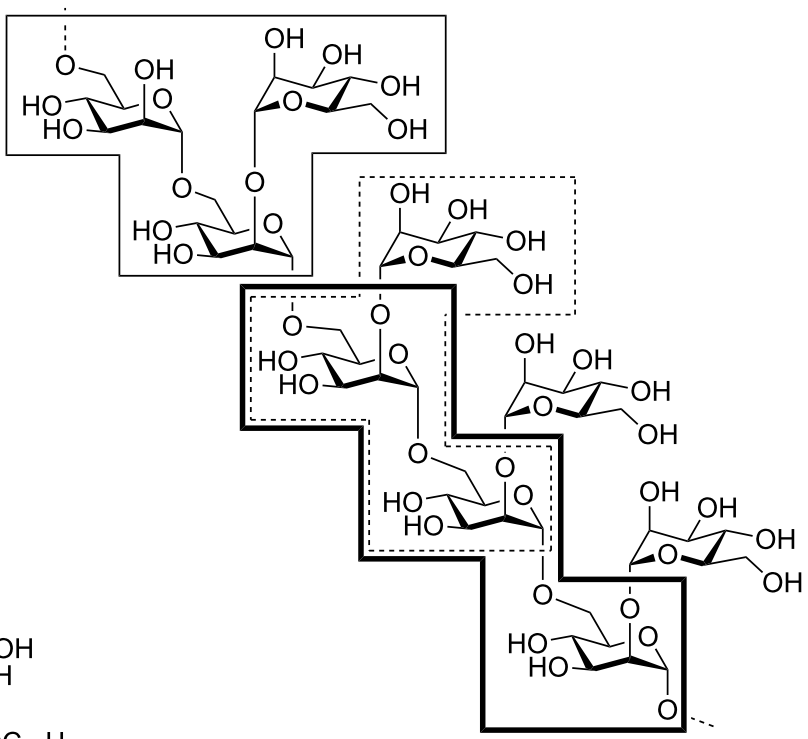

O.

Figure 1: Chemical structures of $(A)$ a representative PIM, $A_{c P I M}$ and $(B)$ a mannan fragment of $L M$ from mycobacteria. Boxes denote the relationship of PIMs and LM to trisaccharide fragments synthesized in this study. 


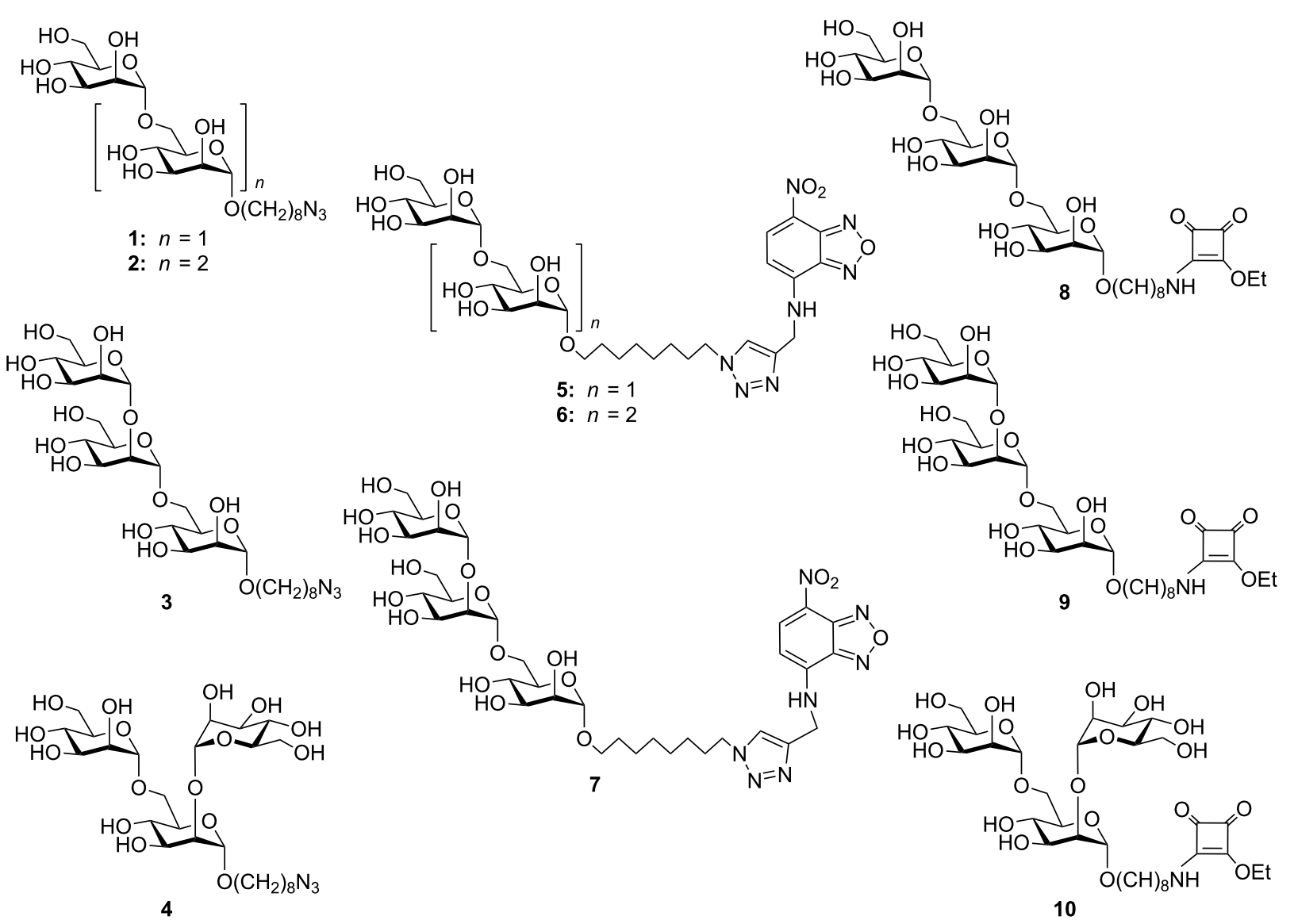

Figure 2: Target di- and trisaccharide glycoconjugate fragments of PIMs and LM.

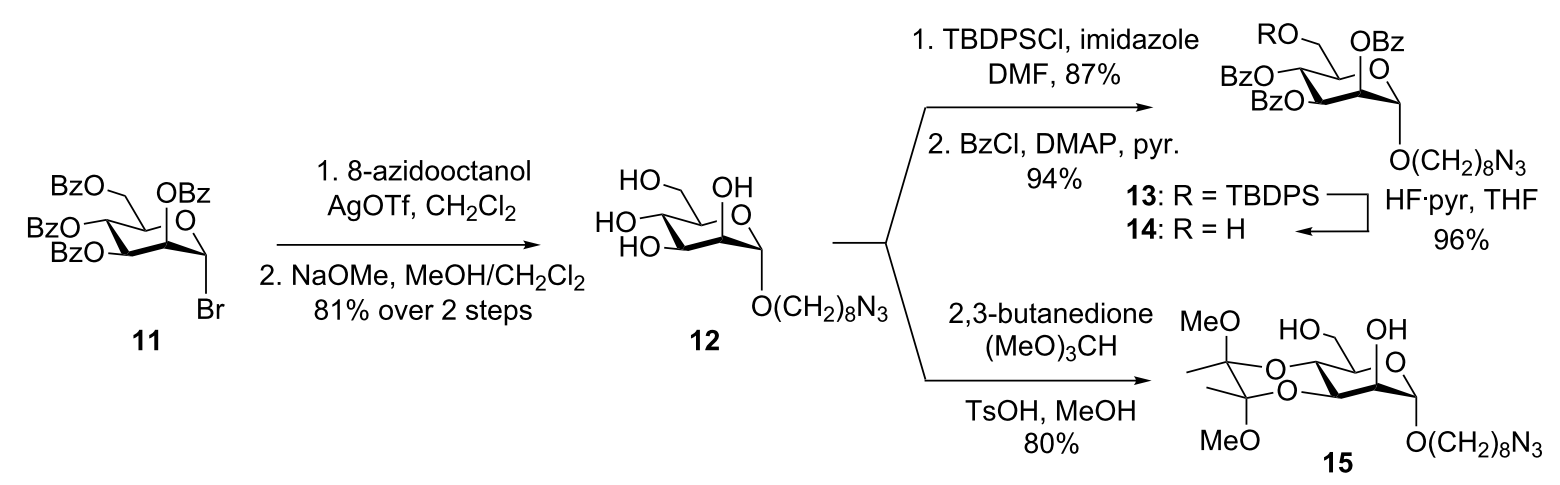

Scheme 2: Synthesis of azidooctyl alcohol 14 and diol 15.

For $\alpha$-mannosylation of primary and secondary alcohols, the mannosyl donors 16 [38] and 17 were used. Treatment of glycosyl bromide 11 with $\mathrm{NaBH}_{4} / \mathrm{KI}$ in $\mathrm{MeCN}$ [39] afforded the crystalline 1,2-O-benzylidene acetal $\mathbf{1 8}$ as a single diastereoisomer in quantitative yield (Scheme 3 ). The stereochemistry of the benzylidene acetal $\mathbf{1 8}$ formed by this method has been studied by Suzuki et al. who assigned the product as the $(7 S)$-stereoisomer (but reported it as the $(7 R)$-isomer) by obser- vation of a nuclear Overhauser effect transfer between the methine proton of the benzylidene acetal and H2 [40]. Unambiguous stereochemical assignment of (7S)-18 was achieved by single crystal X-ray analysis as shown in Figure 3, and is consistent with stereoselective delivery of hydride to the exoface of the intermediate dioxolenium ion. Acetolysis of the benzylidene acetal 18 using $2 \% \mathrm{H}_{2} \mathrm{SO}_{4} / \mathrm{Ac}_{2} \mathrm{O}$ provided diacetate 19 in $60 \%$ yield. Compound 19 was converted into the 


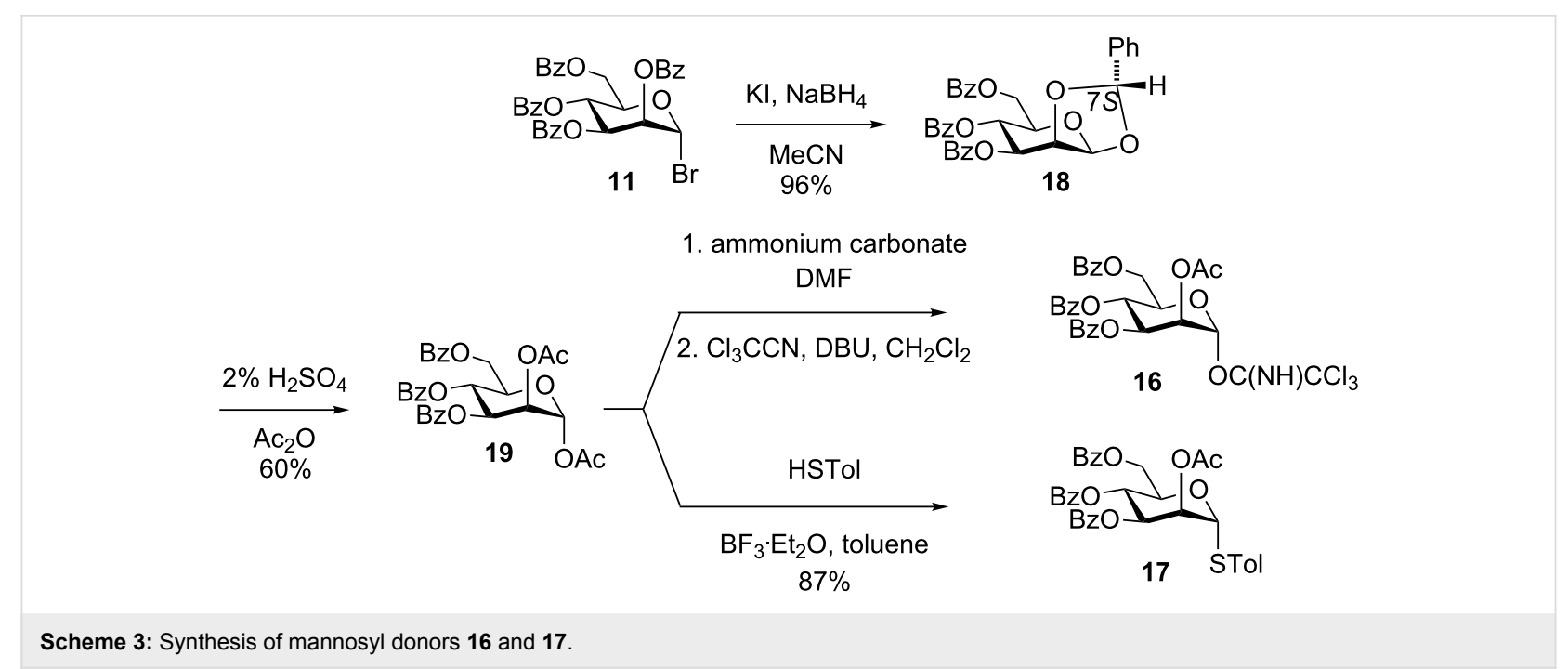

trichloroacetimidate $\mathbf{1 6}$ following the approach of Kong and coworkers [38] or to the thioglycoside 17 by treatment with $p$-thiocresol and $\mathrm{BF}_{3} \cdot \mathrm{Et}_{2} \mathrm{O}$ in toluene.

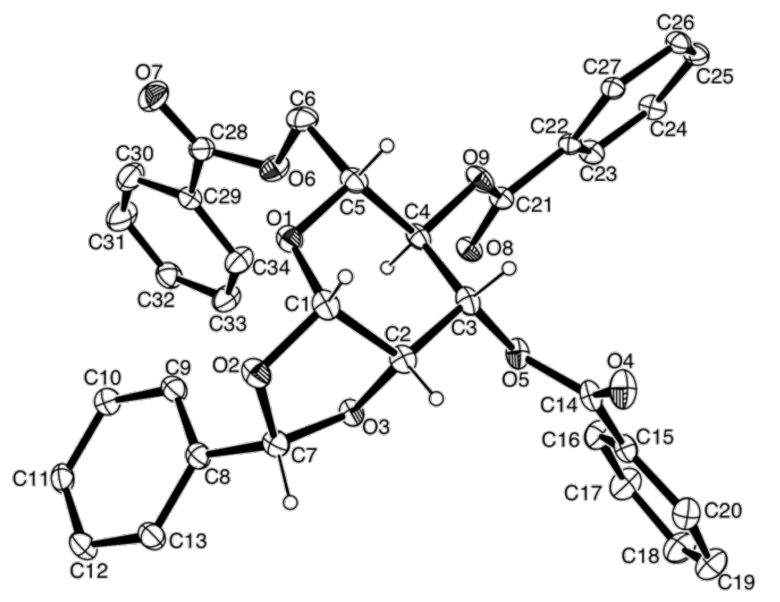

Figure 3: ORTEP plot of single crystal X-ray determination of (7S)-18 Thermal ellipsoids denote $20 \%$ electron probability.

\section{Assembly of mannosides 1-4}

Synthesis of the protected disaccharide $\mathbf{2 0}$ was achieved by glycosylation of $\mathbf{1 4}$ with the thioglycoside donor 21 [41] using NIS/TfOH in $84 \%$ yield (Scheme 4 ). The protected trisaccharide 25 was prepared by an approach similar to that reported for the corresponding octyl trisaccharide $[22,23]$. Thus glycosylation of $\mathbf{1 4}$ with the silylated donor 22 using NIS/TfOH afforded the silylated disaccharide $\mathbf{2 3}$ (99\%). Compound $\mathbf{2 3}$ was desilylated using HF.pyridine and the primary alcohol $\mathbf{2 4}$ was glycosylated using thioglycoside $\mathbf{2 1}$ to give the trimannoside 25. Evidence for the exclusive formation of the $\alpha$-anomer in all mannosylations in this work was obtained through measure- ment of the ${ }^{1} J_{\mathrm{C}, \mathrm{H}}$ coupling constants for the anomeric carbons of the newly formed products. Each coupling constant was $>170 \mathrm{~Hz}$, thereby showing that all new $O$-glycosidic linkages were $\alpha$-configured (Supporting Information File 2) [42]. Global debenzoylation of disaccharide $\mathbf{2 0}$ and trisaccharide $\mathbf{2 5}$ with catalytic $\mathrm{NaOMe}$ in $\mathrm{MeOH} / \mathrm{CH}_{2} \mathrm{Cl}_{2}$ provided $\mathbf{1}$ and $\mathbf{2}$ in yields of $99 \%$ and $94 \%$, respectively.

Our strategy towards the synthesis of the trisaccharide $\mathbf{3}$ sought to utilize a glycosyl donor possessing a 2-O-acetyl group with benzoyl groups at the remaining positions, anticipating that selective deacetylation post-glycosylation could be achieved to allow the subsequent synthesis of the $\alpha$-Man-1,2-Man linkage (Scheme 5). Activation of a mixture of alcohol 14 and trichloroacetimidate 16 at $0{ }^{\circ} \mathrm{C}$ with 0.1 equiv of $\mathrm{BF}_{3} \cdot \mathrm{Et}_{2} \mathrm{O}$ provided disaccharide 26 in only $21 \%$ yield, with a 1,2-glycosyl orthoester as the major product (40\%). Orthoesters are common by-products of glycosylation reactions and typically rearrange under acidic conditions to give trans-linked glycosides [43]. Thus, 14 and 16 were treated with 0.25 equiv of an alternative Lewis acid, TMSOTf, and allowed to react for a longer time to allow the intermediate orthoester to isomerize. Under these conditions the disaccharide $\mathbf{2 6}$ was isolated in an improved yield of $63 \%$. Also isolated was a 6-O-trimethylsilyl ether (6\%), resulting from the reaction of alcohol 14 with TMSOTf. Better still, treatment of $\mathbf{1 4}$ and $\mathbf{1 6}$ with 0.25 equiv of $\mathrm{BF}_{3} \cdot \mathrm{Et}_{2} \mathrm{O}$ afforded 26 in $76 \%$ yield. A similar outcome was obtained using NIS/TfOH activation of thioglycoside donor 17 to furnish disaccharide $\mathbf{2 6}$ in $\mathbf{7 2} \%$ yield. Selective deacetylation of $\mathbf{2 6}$ was achieved by acidic transesterification using 3\% $\mathrm{AcCl}$ in $\mathrm{MeOH} /$ $\mathrm{CH}_{2} \mathrm{Cl}_{2}$ to give the secondary alcohol 27 in $73 \%$ yield. Mannosylation of $\mathbf{2 7}$ using donor $\mathbf{2 1}$ under NIS/TfOH activation gave trisaccharide $\mathbf{2 8}$ in $61 \%$ yield, and global debenzoylation proceeded smoothly to give $\mathbf{3}$. 


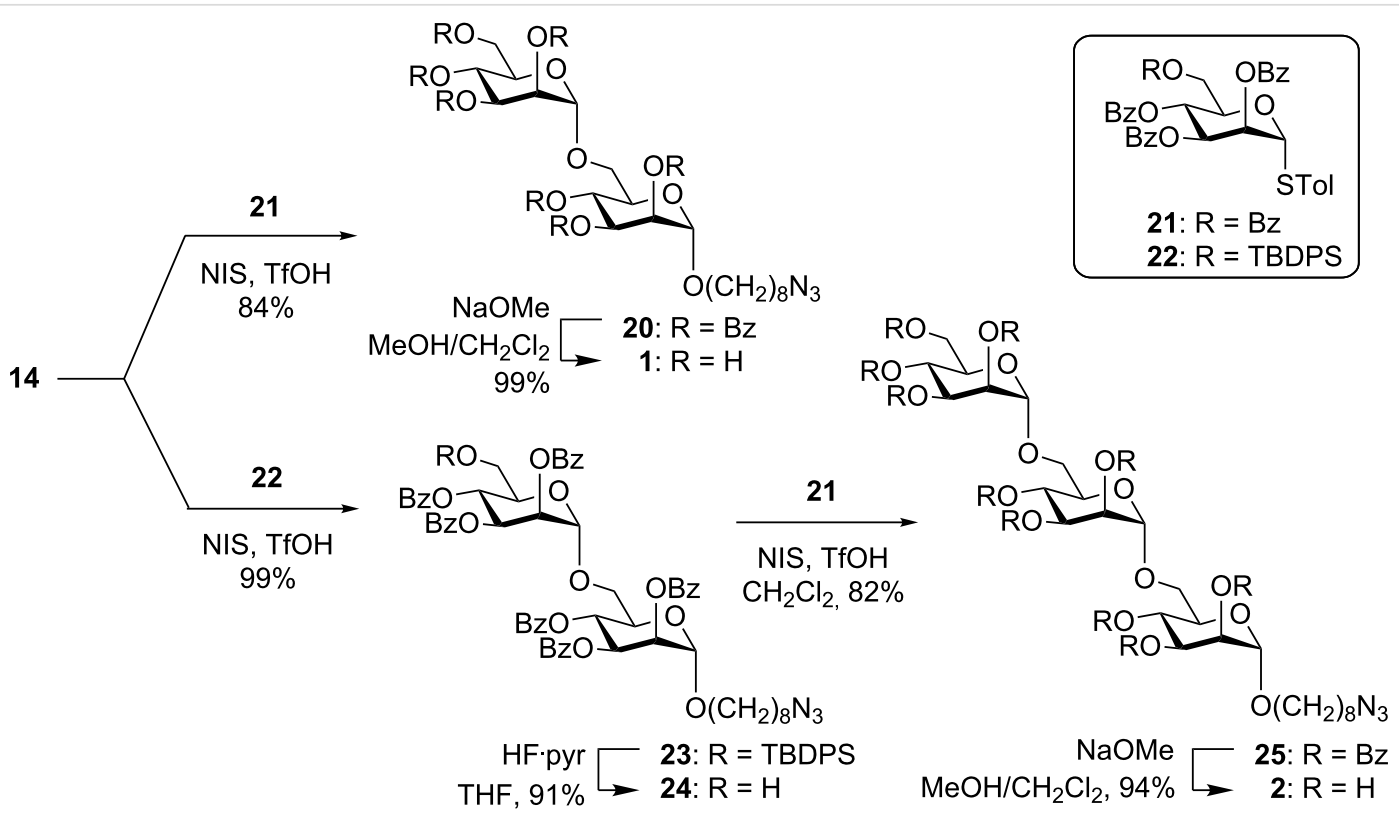

Scheme 4: Synthesis of disaccharide 1 and trisaccharide 2.

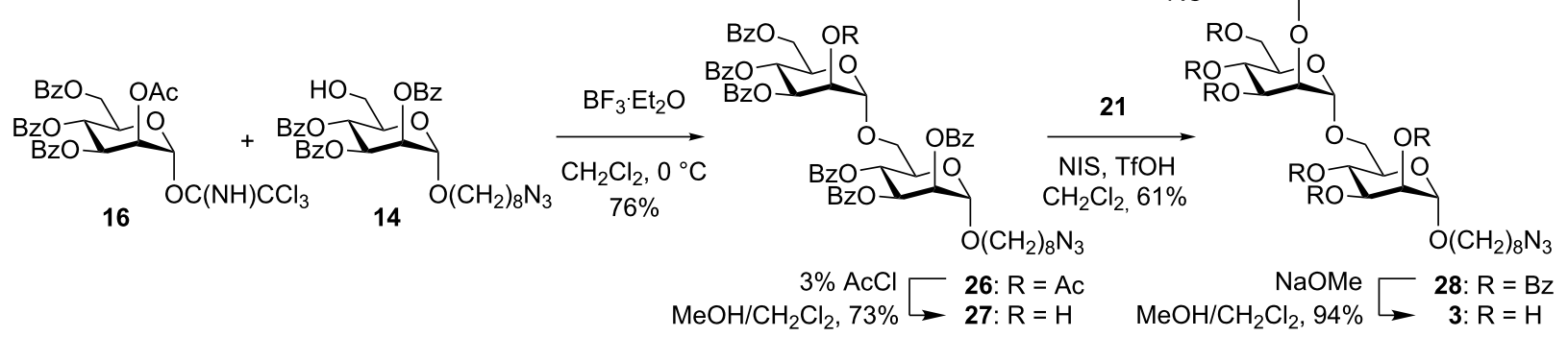

Scheme 5: Synthesis of trisaccharide 3.

The trisaccharide 4 was prepared by simultaneous glycosylation of the 2 and 6 positions of acceptor 15 (Scheme 6). Treatment of the diol 15 with 4 equiv of donor 21, and NIS/TfOH afforded the protected trisaccharide $\mathbf{2 9}$ in $68 \%$ yield. Deprotection was achieved by sequential treatment with TFA/ $\mathrm{H}_{2} \mathrm{O}$ and $\mathrm{NaOMe} / \mathrm{MeOH}$ to afford the trisaccharide 4.

\section{Synthesis of glycoconjugates $5-10$}

Nitrobenzodiazole (NBD) dyes are useful fluorescent labels owing to their small size, low cost, superior water solubility relative to other common alternatives, and ability to be excited using visible, rather than ultraviolet light [44]. Hindsgaul and coworkers have reported the use of glycoconjugates with NBD

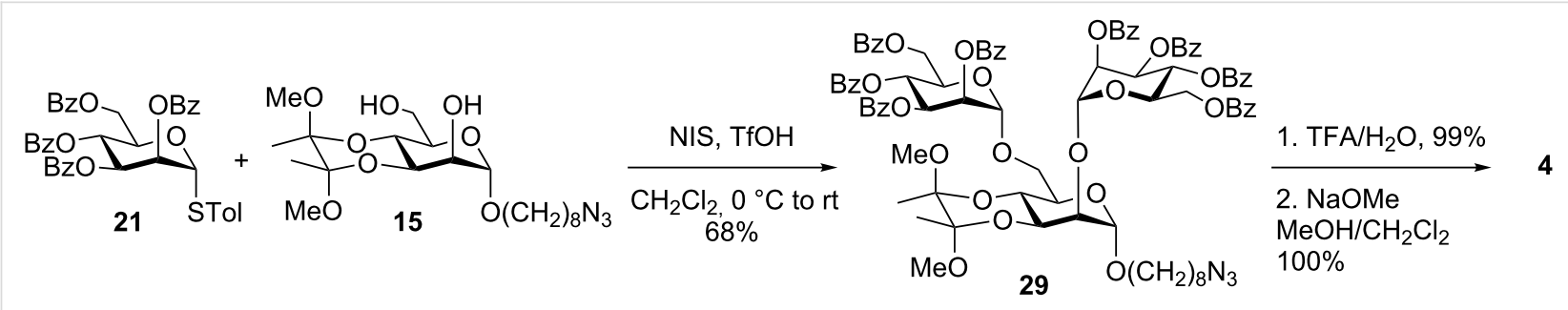

Scheme 6: Synthesis of trisaccharide 4. 
dyes to streamline the detection of carbohydrate-lectin interactions and report that the NBD group displayed substantially less nonspecific interaction with proteins over other fluorescent dyes [45]. Using alkynyl-NBD 30 (prepared in one step from NBD chloride and propargylamine) [34], the disaccharide 1 and trisaccharides $\mathbf{2}$ and $\mathbf{3}$ were coupled upon treatment with $\mathrm{CuSO}_{4}$, sodium ascorbate and the $\mathrm{Cu}(\mathrm{I})$-stabilizing ligand tris(benzyltriazolylmethyl)amine (TBTA) (Scheme 7) [46,47]. The resulting dye-labelled glycoconjugates 5-7 were isolated in 90-95\% yields and possessed excellent fluorescent properties with $\lambda_{\mathrm{ex}}=400 \mathrm{~nm}$ and $\lambda_{\mathrm{em}}=530 \mathrm{~nm}$.

A A 1,2 or 3

$+\mathrm{CuSO}_{4}$

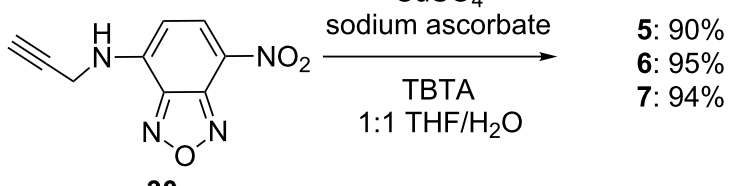
30

B

\begin{tabular}{|c|c|}
\hline & 1. $\mathrm{PPh}_{3}, 3: 1 \mathrm{THF} / \mathrm{H}_{2} \mathrm{O}$ \\
\hline 2,3 or 4 & $\begin{array}{l}\text { 2. diethyl squarate, } \\
\mathrm{EtOH} / \text { buffer } \mathrm{pH} 8\end{array}$ \\
\hline
\end{tabular}

Scheme 7: Synthesis of glycoconjugates 5-7 and 8-10.

The squarate diester methodology introduced by Tietze and coworkers [48] and recently refined by the Kováč group [49] for the attachment of amine-derivatized carbohydrates to carrier proteins has particular advantages over other linker methodologies as diethyl squarate is commerically available and exhibits good selectivity in each coupling step, with the intermediate squaramate ester being sufficiently stable to allow its purification and storage. It should be noted that a key limitation of the methodology is the potential immunogenicity of the squarate group [50]. The three trisaccharides $\mathbf{2}-\mathbf{4}$ were reduced to the aminooctyl derivatives by treatment with $\mathrm{Ph}_{3} \mathrm{P}$ in $\mathrm{THF} /$ water, and treated with diethyl squarate according to the procedure of Kováč (Scheme 7) [49]. Purification by reversed-phase chromatography afforded the ethyl squaramyl derivatives $\mathbf{8}-\mathbf{1 0}$ in $84-94 \%$ yields.

\section{Conclusion}

We report the synthesis of four di/trisaccharide fragments of mycobacterial PIMs/LM/LAM and their elaboration to fluorescently-labelled glycoconjugates and haptens for the preparation of antigens. A readily prepared and crystalline 1,2-O-benzylidene acetal 18 has been used as a central precursor for the preparation of 2-O-acetyl mannosyl donors 16 and $\mathbf{1 7}$. The synthetic routes are compatible with the azido group.

\section{Supporting Information}

\section{Supporting Information File 1}

Experimental part.

[http://www.beilstein-journals.org/bjoc/content/

supplementary/1860-5397-7-47-S1.pdf]

\section{Supporting Information File 2}

${ }^{1} \mathrm{H}$ and ${ }^{13} \mathrm{C}$ NMR spectra for new compounds and fluorescence spectra for 5-7.

The crystallographic data file for the structure reported in this paper has been deposited with the Cambridge Crystallographic Data Centre as file CCDC 804936 and is available on request from http://www.ccdc.cam.ac.uk/. [http://www.beilstein-journals.org/bjoc/content/ supplementary/1860-5397-7-47-S2.pdf]

\section{Acknowledgements}

This work was supported by grants from the Australian Research Council and the National Health and Medical Research Council of Australia. Bradley Coleman and Marcus Angelin are thanked for technical assistance.

\section{References}

1. Dye, C.; Williams, B. G. Science 2010, 328, 856-861. doi:10.1126/science. 1185449

2. WHO: "Tuberculosis" Fact sheet No. 104, November 2010 , http://www.who.int/mediacentre/factsheets/fs104/en/index.html (accessed Jan 18, 2011).

3. Ma, Z.; Lienhardt, C.; Mcllleron, H.; Nunn, A. J.; Wang, X. Lancet 2010 , 375, 2100-2109. doi:10.1016/S0140-6736(10)60359-9

4. Umesiri, F. E.; Sanki, A. K.; Boucau, J.; Ronning, D. R.; Sucheck, S. J. Med. Res. Rev. 2010, 30, 290-326. doi:10.1002/med.20190

5. Janin, Y. L. Bioorg. Med. Chem. 2007, 15, 2479-2513. doi:10.1016/j.bmc.2007.01.030

6. Brennan, P. J.; Nikaido, H. Annu. Rev. Biochem. 1995, 64, 29-63. doi:10.1146/annurev.bi.64.070195.000333

7. Kaur, D.; Guerin, M. E.; Škovierová, H.; Brennan, P. J.; Jackson, M. Adv. Appl. Microbiol. 2009, 69, 23-78. doi:10.1016/S0065-2164(09)69002-X

8. Cao, B.; Williams, S. J. Nat. Prod. Rep. 2010, 27, 919-947. doi:10.1039/c000604a

9. Fischer, K.; Scotet, E.; Niemeyer, M.; Koebernick, H.; Zerrahn, J.; Maillet, S.; Hurwitz, R.; Kursar, M.; Bonneville, M.; Kaufmann, S. H. E.; Schaible, U. E. Proc. Natl. Acad. Sci. U. S. A. 2004, 101, 10685-10690. doi:10.1073/pnas.0403787101

10. Guerin, M. E.; Kordulakova, J.; Alzari, P. M.; Brennan, P. J.; Jackson, M. J. Biol. Chem. 2010, 285, 33577-33583. doi:10.1074/jbc.R110.168328

11. Korduláková, J.; Gilleron, M.; Mikuśová, K.; Puzo, G.; Brennan, P. J.; Gicquel, B.; Jackson, M. J. Biol. Chem. 2002, 277, 31335-31344. doi:10.1074/jbc.M204060200 
12. Lea-Smith, D. J.; Martin, K. L.; Pyke, J. S.; Tull, D.; McConville, M. J.; Coppel, R. L.; Crellin, P. K. J. Biol. Chem. 2008, 283, 6773-6782. doi:10.1074/jbc.M707139200

13. Batt, S. M.; Jabeen, T.; Mishra, A. K.; Veerapen, N.; Krumbach, K.; Eggeling, L.; Besra, G. S.; Futterer, K. J. Biol. Chem. 2010, 37741-37752. doi:10.1074/jbc.M110.165407

14. Korduláková, J.; Gilleron, M.; Puzo, G.; Brennan, P. J.; Gicquel, B.; Mikuśová, K.; Jackson, M. J. Biol. Chem. 2003, 278, 36285-36295. doi:10.1074/jbc.M303639200

15. Guerin, M. E.; Kaur, D.; Somashekar, B. S.; Gibbs, S.; Gest, P.; Chatterjee, D.; Brennan, P. J.; Jackson, M. J. Biol. Chem. 2009, 284, 25687-25696. doi:10.1074/jbc.M109.030593

16. Morita, Y. S.; Patterson, J. H.; Billman-Jacobe, H.; McConville, M. J. Biochem. J. 2004, 378, 589-597. doi:10.1042/BJ20031372

17. Morita, Y. S.; Sena, C. B. C.; Waller, R. F.; Kurokawa, K.; Sernee, M. F.; Nakatani, F.; Haites, R. E.; Billman-Jacobe, H.; McConville, M. J.; Maeda, Y.; Kinoshita, T. J. Biol. Chem. 2006, 281, 25143-25155. doi:10.1074/jbc.M604214200

18. Mishra, A. K.; Alderwick, L. J.; Rittmann, D.; Tatituri, R. V. V.; Nigou, J.; Gilleron, M.; Eggeling, L.; Besra, G. S. Mol. Microbiol. 2007, 65, 1502-1517. doi:10.1111/j.1365-2958.2007.05884.x

19. Mishra, A. K.; Alderwick, L. J.; Rittman, D.; Wang, C.; Bhatt, A.; Jacobs, W. R., Jr.; Takayama, K.; Eggeling, L.; Besra, G. S. Mol. Microbiol. 2008, 68, 1595-1613. doi:10.1111/j.1365-2958.2008.06265.x

20. Kaur, D.; Obregon-Henao, A.; Pham, H.; Chatterjee, D.; Brennan, P. J.; Jackson, M. Proc. Natl. Acad. Sci. U. S. A. 2008, 105, 17973-17977. doi:10.1073/pnas.0807761105

21. Brown, J. R.; Field, R. A.; Barker, A.; Guy, M.; Grewal, R.; Khoo, K. H.; Brennan, P. J.; Besra, G. S.; Chatterjee, D. Bioorg. Med. Chem. 2001, 9, 815-824. doi:10.1016/S0968-0896(00)00300-X

22. Watt, J. A.; Williams, S. J. Org. Biomol. Chem. 2005, 3, 1982-1992. doi:10.1039/b503919c

23. Tam, P. H.; Besra, G. S.; Lowary, T. L. ChemBioChem 2008, 9 , 267-278. doi:10.1002/cbic.200700391

24. Morita, Y. S.; Velasquez, R.; Taig, E.; Waller, R. F.; Patterson, J. H.; Tull, D.; Williams, S. J.; Billman-Jacobe, H.; McConville, M. J. J. Biol. Chem. 2005, 280, 21645-21652. doi:10.1074/jbc.M414181200

25. Subramaniam, V.; Gurcha, S. S.; Besra, G. S.; Lowary, T. L. Tetrahedron: Asymmetry 2005, 16, 553-567. doi:10.1016/j.tetasy.2004.11.063

26. Subramaniam, V.; Gurcha, S. S.; Besra, G. S.; Lowary, T. L. Bioorg. Med. Chem. 2005, 13, 1083-1094. doi:10.1016/j.bmc.2004.11.027

27. Lo Conte, M.; Marra, A.; Chambery, A.; Gurcha, S. S.; Besra, G. S.; Dondoni, A. J. Org. Chem. 2010, 75, 6326-6336. doi:10.1021/jo100928g

28. Tam, P. H.; Lowary, T. L. Org. Biomol. Chem. 2010, 8, 181-192. doi:10.1039/b916580k

29. Gadikota, R. R.; Callam, C. S.; Appelmelk, B. J.; Lowary, T. L. J. Carbohydr. Chem. 2003, 22, 459-480. doi:10.1081/CAR-120025322

30. Tong, M.; Jacobi, C. E.; van de Rijke, F. M.; Kujiper, S.; van de Werken, S.; Lowary, T. L.; Hokke, C. H.; Appelmelk, B. J.; Nagelkerke, N. J. D.; Tanke, H. J.; van Gijlswijk, R. P. M.; Veuskens, J.; Kolk, A. H. J.; Raap, A. K. J. Immunol. Methods 2005, 301, 154-163. doi:10.1016/j.jim.2005.04.004

31. Boonyarattanakalin, S.; Liu, X.; Michieletti, M.; Lepenies, B.; Seeberger, P. H. J. Am. Chem. Soc. 2008, 130, 16791-16799. doi:10.1021/ja806283e
32. Sena, C. B.; Fukuda, T.; Miyanagi, K.; Matsumoto, S.; Kobayashi, K.; Murakami, Y.; Maeda, Y.; Kinoshita, T.; Morita, Y. S. J. Biol. Chem. 2010, 285, 13326-13336. doi:10.1074/jbc.M109.077297

33. Cheng, L.; Chen, Q.; Liu, J.; Du, Y. Carbohydr. Res. 2007, 342, 975. doi:10.1016/j.carres.2007.01.015

34. McGill, N. W.; Williams, S. J. J. Org. Chem. 2009, 74, 9388-9398. doi:10.1021/jo902100q

35. Palcic, M. M.; Heerze, L. D.; Pierce, M.; Hindsgaul, O. Glycoconjugate J. 1988, 5, 49-63. doi:10.1007/BF01048331

36. Ness, R. K.; Fletcher, H. G., Jr.; Hudson, C. S. J. Am. Chem. Soc. 1950, 71, 2200-2205. doi:10.1021/ja01161a091

37. Hense, A.; Ley, S. V.; Osborn, H. M. I.; Owen, D. R.; Poisson, J.-F.; Warriner, S. L.; Wesson, K. E. J. Chem. Soc., Perkin Trans. 1 1997, 2023-2031. doi:10.1039/A702497E

38. Heng, L.; Ning, J.; Kong, F. J. Carbohydr. Chem. 2001, 20, 285-296. doi:10.1081/CAR-100104864

39. Betaneli, V. I.; Ovchinnikov, M. V.; Backinowsky, L. V.; Kochetkov, N. K. Carbohydr. Res. 1982, 107, 285-291. doi:10.1016/S0008-6215(00)80547-9

40. Suzuki, K.; Mizuta, T.; Yamaura, M. J. Carbohydr. Chem. 2003, 22, 143-147. doi:10.1081/CAR-120020483

41. Tam, P.; Lowary, T. L. Carbohydr. Res. 2007, 342, 1741-1772. doi:10.1016/j.carres.2007.05.001

42. Bock, K.; Pedersen, C. J. Chem. Soc., Perkin Trans. 2 1974, 293-299. doi:10.1039/p29740000293

43. Kong, F. Carbohydr. Res. 2007, 342, 345-373. doi:10.1016/j.carres.2006.09.025

44. Ghosh, P. B.; Whitehouse, M. W. Biochem. J. 1968, 108, 155.

45. Dowlut, M.; Hall, D. G.; Hindsgaul, O. J. Org. Chem. 2005, 70, 9809-9813. doi:10.1021/jo051503w

46. Donnelly, P. S.; Zanatta, S. D.; Zammit, S. C.; White, J. M.; Williams, S. J. Chem. Commun. 2008, 7, 2459-2461. doi:10.1039/b719724a

47. Chan, T. R.; Hilgraf, R.; Sharpless, K. B.; Fokin, V. V. Org. Lett. 2004, 6, 2853-2855. doi:10.1021/ol0493094

48. Tietze, L. F.; Schröter, C.; Gabius, S.; Brinck, U.; Goerlach-Graw, A.; Gabius, H.-J. Bioconjugate Chem. 1991, 2, 148-152. doi:10.1021/bc00009a003

49. Hou, S.; Saksena, R.; Kováč, P. Carbohydr. Res. 2008, 343, 196-210. doi:10.1016/j.carres.2007.10.015

50. Wu, X.; Ling, C. C.; Bundle, D. R. Org. Lett. 2004, 6, 4407-4410. doi:10.1021/ol048614m 


\section{License and Terms}

This is an Open Access article under the terms of the Creative Commons Attribution License

(http://creativecommons.org/licenses/by/2.0), which permits unrestricted use, distribution, and reproduction in any medium, provided the original work is properly cited.

The license is subject to the Beilstein Journal of Organic Chemistry terms and conditions:

(http://www.beilstein-journals.org/bjoc)

The definitive version of this article is the electronic one which can be found at:

doi:10.3762/bjoc. 7.47 